\title{
Strategy for Optimizing the Role of MSMEs in Government Good and Services Procurement E-Marketplace
}

\author{
Mustofa Kamal \\ Pusdiklatwas BPKP, Faculty of Law \\ Djuanda University \\ Bogor, Indonesia \\ kamalopek@gmail.com
}

\begin{abstract}
This study aims to examine the development strategy and increase the role of small businesses in the $E$ market place for the procurement of government goods and services. One of the objectives of the procurement of government goods and services is to increase the participation of Micro, Small and Medium Enterprises. At least there are three government policies related to efforts to encourage the achievement of these objectives in the form of; provide opportunities for Micro, Small Business and Medium Enterprises, use information and communication technology and electronic transactions, and develop three Goods / Services Procurement E-marketplaces in the form of electronic catalogs, online stores, and Electronical tendering. Qualitative research is carried out using the applied law research approach. Secondary data analysis is carried out through a literature study of the mandatory policies and theories related to $E$ market place for procurement of government goods, small business development, and innovation. The results showed that MSMEs could use Strength, Weakness, Opportunity and Threat analysis to increase their role in E-marketplace procurement of government goods and services. There are 2 (two) strategies, namely strategies to improve MSME weaknesses in the form of strengthening business legality and innovating through information technology and strategic strategies for cooperation or partnerships between MSMEs and business associations, online stores that are already in PBJP's e-marketplace, with LKPP and Communication and Information Service to be able to innovate in the $E$ marketplace, and with the Office of Cooperatives and Micro, Small and Medium Enterprises in the City / Regency / Province especially to be able to foster and facilitate the strengthening of HR and MSME governance.
\end{abstract}

Keywords- E-market place, small enterprises, innovation

\section{INTRODUCTION}

Micro, Small Business and Medium Enterprises, abbreviated as MSMEs, sector is a sector that has proven to be strong when the economic crisis occurred in Indonesia from 1997 to 1998. Even after the crisis until 2012, the MSME sector was able to absorb 85 million to 107 million workers, the growth in the number of MSMEs increased and became the majority of entrepreneurs 56,534,592 units or $99.99 \%$ of $56,539,560$ business units [1]. Therefore, the government always strives, legally, to improve and strengthen the role of MSMEs. One of them is the provision of government goods and services, abbreviated as PBJP.
One of the goals of the PBJP which is explicitly stated in the Presidential Regulation of the Republic of Indonesia Number 16 Year 2018 concerning PBJP, abbreviated as Perpres $16 / 2018$, is to increase the participation of MSMEs. To encourage the achievement of the PBJP objectives, there are at least 3 (three) PBJP policies, among others, providing opportunities for MSMEs, using information and communication technology and electronic transactions, and developing PBJP's E-marketplace. PBJP's E-marketplace is an electronic market that is provided to meet the needs of government goods / services. From this mandatory, the first research question arises; what is the government's strategy in in developing and increasing the role of MSMEs in PBJP's E-marketplace?

Previous studies discussed strategies for developing MSMEs, among others; use of market penetration strategies [2], government policy support, business associations, universities and related institutions [3]. Meanwhile, some researchers use analysis of Strength, Weakness, Opportunity and Treath, abbreviated as SWOT. The results are cost advantage strategies and differentiation strategies [4], growth or growth strategies [5], capital development [6].

If reviewed from the mandatory improvement of the role of SMEs and use of PBJP's E-Marketplace, and some previous research findings on SME development strategies, the authors developed a second research question, namely; how is the development strategy of MSME in PBJP's Emarketplace?. Therefore, this study aims to provide alternative government strategies to achieve the role of small business role in e-marketplace PBJP and alternative strategies that can be used by MSME in order to play a part in PBJP's e-marketplace. Furthermore, this paper will be presented in the order of literature review, research method, discussion and conclusion.

\section{LITERATURE REVIEW}

\section{A. MSMEs and E-Marketplace in PBJP}

Perpres 16/2018 decalred that MSMEs are productive economic businesses that are independent and carried out by individuals or business entities that meet the criteria of MSMEs in accordance with regulations, that means is Law 20/2008. It also also states that one of the goals of PBJP is to increase the participation of MSMEs. To encourage this, the government explicitly stated that the value of packages for the procurement of goods/ construction/other services that need to be reserved and intended for micro and small 
business shall be in the maximum amount of IDR 2,500,000,000.00 (two billion five hundred million rupiah).

Perpres 16/2018 explicitly reveals the definition of Emarketplace for Procurement of Goods/Services, namely; electronic market provided to meet government goods / services needs electronically. PBJP's E-marketplace provides technical infrastructure and transaction support services for Ministries/Institutions/Regional Governments, abbreviated as KLPD, and Providers in the form of 3 (three), namely; Electronic Catalog, Online Store; and Selection of Providers.

Electronic catalogs can be in the form of national electronic catalogs, sectoral electronic catalogs, and local electronic catalogs. Electronic catalog contains information in the form of lists, types, technical specifications, local content, domestic products, SNI products, green industry products, country of origin, prices, providers, and other information related to goods / services.

The government has the mandate to develop an Electronic Procurement System, abbreviated as SPSE, which consists of; Procurement Planning, Procurement Preparation, Selection of Providers, Contract Implementation, Job Handover, Management of Providers, and Electronic Catalog. SPSE is also expected to have interconnections with planning, budgeting, payment, information systems, asset management, and other information systems related to SPSE.

The government also has a mandate to develop SPSE support systems which include; National Procurement Portal, Management of Human Resources in PBJP, Management of advocacy and resolution of legal issues, Management of community participation, Management of learning resources, and Monitoring and Evaluation.

The function of SPSE must serve; management of all information systems for the procurement and infrastructure, implementation of user registration and verification of all Procurement information systems, and development of information systems needed by stakeholders. Coaching and supervision of LPSE will be carried out by the Government Procurement Policy Institution, abbreviated as LKPP.

Furthermore, Perpres 16/2018 also states that KLPD forms a work unit for the procurement of goods, abbreviated as UKPBJ, has the task of providing support for the procurement to KLPD. UKPBJ has a function;. management of Goods/Services Procurement, management of electronic procurement services, human resource development and institutional procurement, implementation of assistance, consultation and/or technical guidance, and carrying out other duties given by head of KLPD.

KLPD are obliged to supervise PBJP through the internal auditor of KLPD. The scope of supervision of PBJP includes: achievement of value for money, compliance with regulations; achievement of TKDN, use of domestic products, package backup and designation for small businesses, Sustainable Procurement. The results of supervision are used as a control tool for the implementation of PBJP.

Then, LKPP has the authority to develop, foster, manage, and supervise the implementation of PBJP's E- marketplace. In order to develop and manage PBJP's Emarketplace, LKPP can work together with UKPBJ and/or Business Actors as well as compiling and establishing PBJP's E-marketplace development roadmap.

For PBJP's e-marketplace development, LKPP and other government agencies need to implement whole of government, abbreviated as WoG. There are 3 (three) key aspects in WoG, namely coordination, capacity and egovernment. WoG can be applied in 4 forms, namely strengthening coordination between institutions, forming special coordinating institutions, forming task forces and social coalitions. The task force is a form of institutionalization of coordination carried out outside the formal structure, whose eel is not permanent.

The social coalition is an informal form of uniting coordination between sectors or institutions, without the need to form special institutionalization in this coordination. Social coalition initiatives can be encouraged between government actors, businesses and community groups. This social coalition encourages the equalization of values and perceptions of things, so that in the end there will be natural coordination [7].

\section{B. Previous Research on MSME Development Strategies}

The development of MSMEs of course also needs to be done by MSMEs themselves. There are several studies or studies on the strategies for developing MSMEs that have been carried out by several researchers. There is a strategy to develop MSMEs in strengthening people's economy in the Maros Roti Business in Maros Regency [2]. Qualitative analysis uses triangulation data collection techniques and SWOT analysis techniques. The results of his research show that market and product strategies, as well as intensive market penetration by increasing promotion, quality, and innovation of Maros Bread products.

Meanwhile, a study of business strategies in 3 bamboobased craft SMEs in the city of Bandung. The results of the SWOT analysis and Porter Generic Strategy show that all three MSMEs have implemented Porter Generic Strategy well [4]. However, the strategy of cost excellence was only implemented by Haur Bamboo, and the strategy of differentiation and focus was applied by Sari Kurnia and Virage Awi.

While the study of development strategies and increased competitiveness in the face of the free market competitive ASEAN Economic Community (AEC) 2015, in MSMEs in the city of Tarakan, North Kalimantan [5]. The results of the study show that the growth strategy can be used in the form of maintaining the quality of raw materials, product legality/permits that are included in the qualifications, prices that remain competitive and increasing HR.

In other places, there is a study of reviewing the strategies for developing MSMEs in the Yogyakarta Special Province [3]. The results of his research show that the development of MSMEs is not only by MSMEs, but also must be supported by government policies and all stakeholders, including; business associations, universities, and related institutions in regencies / cities in DIY. In the same province, there was also a study of the use of SWOT analysis in the strategy of developing MSME Warmindo Wala Weleu [6]. The results show the strategy used in the 
form of developing capital through the application of accounting in fund management and the development of marketing through product promotion.

SWOT analysis is done by identifying weaknesses, opportunities and challenges [8]. There are two main steps in a SWOT analysis, namely; parse everything in the 4 main components of the SWOT analysis and make a strategy based on the SWOT matrix [9].

From the mandatory description of the increased role of MSMEs above and some previous research on MSME development strategy, the authors developed a second research question, namely; how is the mandatory application of regulations and some previous research as a strategy to achieve PBJP's goals of increasing the role of SMEs in Emarketplace PBJP?. Therefore, this study aims to provide alternative government strategies to achieve the role of small business role in e-marketplace PBJP and alternative strategies that can be used by small businesses to play a role in e-marketplace PBJP.

\section{METHODOLOGY}

This research is a qualitative research with the applied law research approach. Data sources used in the form of primary legal materials, secondary legal materials, and tertiary legal materials. Primary legal materials are legal materials that have juridical binding powers in the form of laws and regulations. Secondary legal material is legal material that is closely related to primary legal materials, such as; scientific papers and journals. Whereas tertiary legal material is complementary to secondary legal materials, for example in the form of legal, index and bibliographic dictionaries [10].

According to Abdulkadir Muhammad, the applied law research stage is 2 (two), namely; the stage of study of normative law and the stage of study of the implementation of law in achieving predetermined golas [10]. The results of implementation will create an understanding of the realization of the implementation of normative legal provisions that have been properly reviewed or not. The scope of normative law used is normative law concerning $\mathrm{E}$ marketplace, PBJP, and MSME. The object of this study is limited to efforts to achieve PBJP goals, implementation of PBJP policies and projections of the role of small businesses in PBJP.

Sources of data or primary legal material in the form of laws, government regulations, presidential regulations and ministerial regulations. While the secondary legal material in the form of research results and related journals. BPS data and some information from the websites of institutions or organizations related to research objects will also be used as complementary legal material. The research process is carried out with the steps in Figure 1 as follows:

\begin{tabular}{|c|}
\hline literature studies related to E-marketplace and MSME Strategy \\
\hline mandatory \\
\hline Increasing the role of MSMEs in E-marketplace \\
\hline government strategy \\
\hline Conclusion of MSME development strategies in PBJP's E- \\
marketplace \\
\hline
\end{tabular}

Fig. 1. Research Process

\section{RESUlt AND DisCUSSION}

\section{A. Government Strategy for Increasing the Role of MSMEs} in PBJP's E-marketplace

One of the considerations in Law 20/2008 states that the empowerment of MSMEs needs to be carried out thoroughly, optimally and sustainably through the development of a conducive climate, providing opportunities for business, support, protection and business development to the greatest extent so as to increase position, role, and the potential of Micro, Small and Medium Enterprises in realizing economic growth, equity and increasing people's income, job creation, and poverty alleviation

While Law 20/2008, mandates that empowerment is an effort carried out by KLPD, Business World, and the community in a synergistic manner in the form of climate growth and business development for MSME so that it can grow and develop into a strong and independent business. Business climate is a condition pursued by the KLPD to empower MSME synergistically through the stipulation of various laws and policies and policies in various aspects of economic life so that MSME get partiality, certainty, opportunity, protection, and business support as wide as possible. Meanwhile, development is an effort made by KLPD, Business World, and the community to empower MSME through the provision of facilities, guidance, assistance, and reinforcement assistance to grow and enhance the capabilities and competitiveness of MSMEs.

There are 3 (three) goals for empowering MSMEs in Law 20/2008, namely; a. realize the structure of a national economy that is balanced, developing, and just; b. grow and develop the ability of MSMEs to be strong and independent businesses; and c. increasing the role of MSMEs in regional development, job creation, income distribution, economic growth, and alleviating people from poverty. To achieve this goal, the empowerment of MSMEs must be carried out according to 5 (five) principles of empowerment, namely; a. growing the independence, togetherness and entrepreneurship of MSMEs to work with their own initiatives; b. the realization of public policies that are transparent, accountable and fair; c. regional potential based business development and market oriented in accordance with MSME competencies; d. increasing the competitiveness of MSMEs; and e. implementation of integrated planning, implementation and control.

In addition, the growth of the business climate for MSMEs also needs to be done. Law 20/2008 has given a role to the government, regional government, business world and society. KLPD foster the Business Climate by establishing legislation and policies covering aspects; a. funding; b. facilities and infrastructure; c. business information; d. partnership; e. business licensing; f. business opportunity; g. trade promotion; and h. institutional support. Meanwhile, the Business World and the community actively participate in helping to grow the Business Climate

The synergy of the government, business world and society in the growth of the MSME business climate is in accordance with the concept of the three pillars of good governance. The concept of good governance is the whole 
set of process that synergizes the achievement of the three pillars of good governance, namely the government as a good public governance, society and private business world as good corporate governance [11]. From the few paragraphs above, the relationship between the 3 pillars of governance can be revealed to achieve MSME empowerment in Figure 2 as follows:

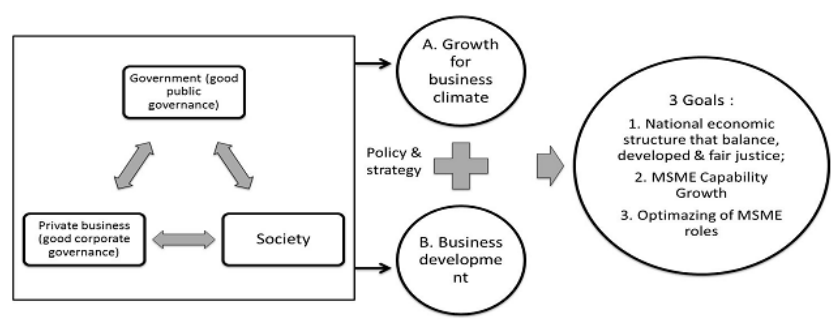

Source: UU No. 20/2008, Kamal and Elim (2018). Processed by author

Fig. 2. Three Governance actors and Three Goals of Optimizing Role of MSME

The figure above reflects that the 3 goals of MSME empowerment must be achieved through the growth of the business climate and business development for MSMEs. The three parties in the governance pillar must work together in an effort to grow the business climate and develop MSME businesses. From the government side, the mandate for empowering MSMEs is increasingly intense, especially in the fields of PBJP and E-marketplaces. Perpres 16/2018 explicitly discloses several mandates in table I as follows:

TABLE I. MANDATORY IMPROVEMENT IN THE ROLE OF MSMES AND E-MARKETPLACE IN PERPRES 16/2018

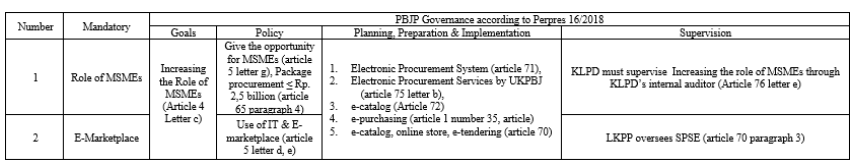

The contents of the table above reflect that the government has tried to create a conducive climate for enhancing the role of MSMEs, such as point A in Figure 2, through several improvements in regulation-based procurement governance. However, if viewed from the participation of providers registered in LPSE and the number of MSMEs in 2017, the provider participation rate compared to the number of MSMEs is still low. There are $0.64 \%$ of providers registered in LPSE compared to the number of MSMEs or 401,356 providers of the number of MSMEs of 62,922,617.

TABLE II. AMOUNT OF MSME AND AMOUNT OF SUPPLIER IN LPSE

\begin{tabular}{|c|c|c|c|}
\hline Year & MSME & $\begin{array}{c}\text { Supplier in } \\
\text { LPSE }\end{array}$ & $\begin{array}{c}\text { \% supplier } \\
\text { from } \\
\text { MSME }\end{array}$ \\
\hline 2017 & 62.922 .617 & 401.356 & 0,64 \\
\hline 2016 & 61.651 .177 & 401.356 & 0,65 \\
\hline 2015 & 59.262 .772 & 373.597 & 0,63 \\
\hline 2014 & 57.895 .721 & 333.505 & 0,58 \\
\hline 2013 & 56.534 .592 & 333.505 & 0,59 \\
\hline 2012 & 55.206 .444 & 277.380 & 0,50 \\
\hline 2011 & 54.114 .821 & 174.379 & 0,32 \\
\hline 2010 & 52.764 .750 & 55.856 & 0,11 \\
\hline \multicolumn{5}{|c|}{$\begin{array}{c}\text { http://www.depkop. } \\
\text { go.id/uploads/lapora } \\
\text { n/1549946778_UM } \\
\text { KM\%202016- }\end{array}$} \\
\multicolumn{4}{|c|}{ hsse.lkpp.go.i } \\
\hline
\end{tabular}

2017\%20rev.pdf

This condition can be a signal that at the beginning of the implementation of PBJP's E-marketplace that the role of MSMEs has not been optimal. This has the potential to threat the achievement of the goals of empowering MSMEs and the goals of PBJP. The government needs to seriously synergize with the business world and the community to design MSME business development strategies, such as point $\mathrm{B}$ in figure 2 .

The government needs to improve the provision of facilities, guidance, assistance and reinforcement assistance to grow and improve the capabilities and competitiveness of MSME. To ensure that this works well, LKPP needs to work together with the KLPD's internal auditor to supervise the achievement of the goal of increasing the role of MSMEs in E-Marketplace

\section{B. Strategy for Optimazing the Role of MSMEs in PBJP's E-Marketplace}

MSMEs mean part of the three pillars of governance as in Figure 2. Therefore MSMEs must also improve and actively develop business and innovate well. if MSMEs will develop their business in the PBJP E-marketplace, MSMEs need to look at a number of opportunities that exist from the mandate of Perpres 16/2018. MSMEs can use SWOT analysis. MSMEs need to analyze internal strengths and weaknesses and analyze external opportunities and challenges.

From the internal side of MSMEs, some of the internal strengths that MSMEs can use are in the form of; cost advantages [4], [5], product quality [2], [5], the application of accounting in reporting [6]. While some weaknesses of MSMEs in the form of product legality do not yet exist [5], and weaknesses in e-marketplace are as follows:

- MSME does not have the human resources with the necessary understanding of the information technology

- even if E-Commerce is implemented, its usefulness within the MSMEs is still unknown,

- complexity of the use of E-Commerce a barrier for MSMEs people who do not understand the technology,

- for its successful implementation, the MSME business processes need to be adjusted,

- limited technology infrastructure to support ECommerce adoption for MSME [12].

Meanwhile, the external side of MSMEs has opportunities and threats. There are several opportunities in the form of PBJP's e-marketplace, government programs and policies, business associations and universities [3]. While some external threats can come from prospective buyers. The threat can be in the form of:

- Buyers in the marketplace are less confident about the seller validity,

- Buyers in marketplace are comfortable using the account transfer payments via ATM and Cash On Delivery (COD),

- Buyers have more confidence in the seller if there is recommendation from known friend, as well as some previous customer testimonials,

- Buyers need information on company profiles and company verification, 
- In the user profile feature, buyers need information on transaction history that has been done [12].

Two strategies can be carried out by MSMEs, namely strategies to improve weaknesses and strategies for cooperation or partnership. In the strategy of correcting weaknesses; MSMEs need to strengthen business legality and innovate through information technology. In the strategy of cooperation or partnership; MSMEs need to work with business associations, online stores that are already in the PBJP's e-marketplace. MSMEs also need to build partnerships with LKPP and the Communication and Information Service to innovate in information technology so they can play a role in E-marketplace. In addition, MSMEs also need to actively collaborate with the Office of Cooperatives and micro, small and medium enterprises in the City/Regency/Province, especially to provide guidance and facilitation for strengthening Human Resources and MSME governance.

\section{CONCLUSION}

There are 2 (two) objectives of this study, namely to provide an alternative strategy for the government to achieve an increase in the role of small businesses in PBJP emarketplace and alternative MSME strategies in order to play a role in PBJP's e-marketplace. The results of the study shows that the government needs to design a strategy to improve guidance and assistance to strengthen MSME governance and the synergy of LKPP with the government internal auditor to supervise the achievement of the goal of increasing the role of MSMEs in E-Marketplace.

The second research finding is a strategy that can be taken by MSMEs. There are 2 (two) strategies, namely strategies to improve MSME weaknesses in the form of strengthening business legality and innovating through information technology and strategies for cooperation or partnerships between MSMEs and business associations, online stores in the PBJP e-marketplace, between MSMEs and LKPP and the Goverment Communication and Information Service to be able to innovate in the Emarketplace, and also between MSMEs and the government institution for Cooperative and MSME in the City/Regency/Province, especially to provide guidance and facilitation for strengthening HR and MSME governance.
This study has limited data on the number of non-detailed providers between MSMEs and non-MSMEs. So that the level of participation of providers that are truly MSMEs can be even smaller. Other limitations in the form of regulations used are only Law 20/2008 and Perpres 16/2018 due to limited access.

\section{REFERENCES}

[1] Suci Y.R., perkembangan umkm (usaha mikro kecil dan menengah) di indonesia, Jurnal Ilmiah Cano Ekonomos, Vol. 6 No. 1 Januari 2017

[2] Alyas dan Rakib M., Strategi Pengembangan Usaha Mikro, Kecil dan Menengah dalam Penguatan Ekonomi Kerakyatan (Studi Kasus pada Usaha Roti Maros di Kabupaten Maros), Jurnal Sosiohumaniora, Volume 19 No. 2 Juli 2017 : 114 - 120

[3] Hamid E. S. dan Susilo Y. S., Strategi pengembangan usaha mikro kecil dan menengah di provinsi daerah istimewa yogyakarta, Jurnal Ekonomi Pembangunan Volume 12, Nomor 1, Juni 2011, hlm.45-55

[4] Abdillah M.B., Hakim R.M.A., Damiri D.M, dan Zahra F., Analisis strategi bisnis pada umkm kerajinan bambu di kota bandung, Jurnal AdBispreneur, Vol. 2, No. 3, Desember 2017, Hal. 227-242

[5] Ariani dan Utomo M.N., Kajian strategi pengembangan usaha mikro kecil dan menengah (UMKM) di kota tarakan, Jurnal Organisasi dan Manajemen, Volume 13, Nomor 2, September 2017, 99-118

[6] Agnefa A.C., Strategi Pengembangan Usaha Mikro Kecil Menengah Warmindo Wala Weleu Berdasarkan Analisis SWOT, Skripsi di Program Studi Pendidikan Ekonomi, Bidang Keahlian Khusu Pendidikan Akuntansi, Universitas Sanata Dharma, Yogyakarta, 2018

[7] LAN, whole of government, Modul Pelatihan Dasar Calon PNS, Lembaga Administrasi Negara, Jakarta, 2017

[8] BPKP, Analisis Kebijakan Publik, Moduk Diklat JFA penjenjangan tingkat madya, Pusdiklatwas BPKP, Bogor, 2014

[9] Zhafran Ghani Al Rafisqy, Contoh Analisis SWOT | Lengkap Pengertian, Tujuan, Manfaat, dan Cara Membuatnya, https://ekspektasia.com/contoh-analisis-swot/2017, diakses 27 Juni 2019

[10] Suteki dan Taufani G, Metodologi Penelitian Hukum (Filsafat, Teori dan Praktik), PT Rajagrafindo Persada, Depok, 2018

[11] Kamal Mustofa dan Elim John, Governance strategy of goverment procurement: retrospective case study, Presentasi paper (call for paper) di konferensi internasional ICAS PGS 2 FIA UI, Hotel Aston Simatupang, Jakarta Selatan, 30 Oktober 2018

[12] Syuhada Ahmad Anshorimuslim dan Gambetta Windy, Online Marketplace for Indonesian Micro Small and Medium Enterprises Based on Social Media, The 4th International Conference on Electrical Engineering and Informatics (ICEEI 2013), Procedia Technology 11 ( 2013 ) 446 - 454, Published by Elsevier Ltd. 